\title{
Phylogeny and photosynthetic features of Thiobacillus acidophilus and related acidophilic bacteria: its transfer to the genus Acidiphilium as Acidiphilium acidophilum comb. nov.
}

\author{
Akira Hiraishi, ${ }^{1}$ Kenji V. P. Nagashima, ${ }^{2}$ Katsumi Matsuura, ${ }^{2}$ \\ Keizo Shimada, ${ }^{2}$ Shinichi Takaichi, ${ }^{3}$ Norio Wakao ${ }^{4}$ and Yoko Katayama ${ }^{5}$
}

Author for correspondence: Akira Hiraishi. Tel: +8153244 6913. Fax: +81532446929.
e-mail: hiraishi $(a$ eco.tut.ac.jp

1 Department of Ecological Engineering, Toyohashi University of Technology, Toyohashi 441, Japan

2 Department of Biology, Tokyo Metropolitan University, Hachioji 192-03, Japan

3 Biological Laboratory, Nippon Medical School, Kawasaki 211, Japan

4 Department of Bioscience and Technology, Iwate University, Morioka 020, Japan

5 Department of Environmental and Natural Resources Science, Tokyo University of Agriculture and Technology, Fuchu 183, Japan

\begin{abstract}
Phylogenetic analyses based on 165 rDNA sequences and genomic DNA-DNA relatedness showed that the sulphur-oxidizing facultative chemolithotroph Thiobacillus acidophilus was closely related to members of the genus Acidiphilium, which is a group of strictly aerobic, heterotrophic acidophiles now categorized into aerobic photosynthetic bacteria. Lipophilic pigment analyses revealed that zinc-chelated bacteriochlorophyll $a$ and carotenoids occurred in appreciable amounts in $T$. acidophilus and all established species of the genus Acidiphilium. PCR experiments showed that $T$. acidophilus as well as Acidiphilium species contained puf genes, encoding the photosynthetic reaction centre proteins and the core light-harvesting complex of the purple bacteria. There were high similarities between $\boldsymbol{T}$. acidophilus and Acidiphilium species in the primary structure of their reaction centre proteins deduced from the nucleotide sequence data. The phylogenetic tree of the reaction centre proteins was in agreement with the 165 rDNA sequence-based phylogenetic tree in the relationship between $T$. acidophilus and Acidiphilium species and between the Acidiphilium cluster and other purple photosynthetic bacteria. Based on these results, together with previous phylogenetic and phenotypic information, it is proposed to reclassify $T$. acidophilus (Guay and Silver) Harrison 1983 as Acidiphilium acidophilum comb. nov. The type strain is ATCC $27807^{\top}$ ( = DSM 700').
\end{abstract}

Keywords: Thiobacillus acidophilus, zinc-bacteriochlorophyll, photosynthetic reaction centre, phylogeny, Acidiphilium acidophilum comb. nov.

\section{INTRODUCTION}

The genus Thiobacillus is a group of obligately or facultatively chemolithotrophic aerobic proteobacteria that are capable of growing with reduced inorganic sulphur compounds as sole energy source, but, at this time, is quite heterogeneous with members exhibiting a wide range of physiological, chemotaxonomic and genetic characteristics (KatayamaFujimura et al., 1982, 1983; Kelly \& Harrison, 1989; Lane et al., 1985, 1992). This group encompasses a

Abbreviations: BChl, bacteriochlorophyll; BPhe, bacteriopheophytin. The DDBJ accession numbers for the 165 rDNA sequences determined in this paper are D86508, D86509, D86511, D86513 and AB006712; for the puf gene the number is $A B 013379$. number of acidophilic species (Harrison, 1984; Pronk et al., 1990), including Thiobacillus acidophilus, in addition to neutrophilic thiobacilli. The name $T$. acidophilus was proposed by Guay \& Silver (1975) for some strains of facultatively chemolithotrophic acidophilic thiobacilli, but did not appear on the Approved Lists of Bacterial Names (Skerman et al., 1980). Harrison (1983) revived the name $T$. acidophilus following his confirmation that this organism grew equally well with elemental sulphur or glucose as a sole energy source. Phylogenetic analyses based on 5S rRNA sequences (Lane et al., 1985) and partial 16S rRNA sequences (Lane et al., 1992), however, indicated that T. acidophilus was far distant from any other Thiobacillus species and was closely related to species of the genus Acidiphilium, which includes aerobic 
acidophilic chemo-organotrophic bacteria that are unable to use reduced sulphur compounds as energy source (Harrison, 1989; Kishimoto et al., 1995b). Despite the dissimilarity in sulphur metabolism between T. acidophilus and Acidiphilium species, the available phylogenetic information has strongly suggested that the former species should be positioned among members of the genus Acidiphilium.

Recent research has shown that Acidiphilium species can be categorized into a group of aerobic photosynthetic bacteria (Shimada, 1995) because of their production of bacteriochlorophyll (BChl) only under aerobic growth conditions and their photosynthetic activity (Kishimoto et al., 1995a; Wakao et al., 1993, 1994). Interestingly, it has been shown more recently that a representative member of Acidiphilium, Acidiphilium rubrum, contains a fully active photosynthetic system with zinc-chelated bacteriochlorophyll (Zn-BChl) $a$ as the major pigment (Wakao et al., 1996). This was the first demonstration of the existence of natural photosynthesis using (bacterio-)chlorophylls containing a metal other than magnesium. Further studies have shown that all established species of the genus Acidiphilium contain the puf operon (Nagashima et al., 1997b), which is an assemblage of genes encoding the proteins of the photosynthetic reaction centre (L, M and $\mathrm{C}$ subunits) and the core light-harvesting complex ( $\alpha$ and $\beta$ subunits) of the purple photosynthetic bacteria. The structure of the puf operon is well-conserved among species of these bacteria, and thus the PCR technique is applicable for detection of a conserved region of puf genes (Nagashima et al., 1997a, b).

These recent findings motivated us to re-evaluate the phylogenetic relationships between $T$. acidophilus and members of the genus Acidiphilium and to determine whether T. acidophilus has photosynthetic properties. A previous study undertaken to detect photopigments in $T$. acidophilus gave negative results (Kishimoto et al., 1995a), but our attempts to find $\mathrm{Zn}-\mathrm{BChl} a$ and puf genes in T. acidophilus, as well as in all Acidiphilium species, have been successful. Phylogenetic analyses based on 16S rDNA sequences, genomic DNA-DNA relatedness and the $L$ and $M$ subunit proteins of the reaction centre demonstrated that there were close relationships between T. acidophilus and Acidiphilium species. These results led us to conclude that $T$. acidophilus should be transferred to the genus Acidiphilium as Acidiphilium acidophilum comb. nov.

\section{METHODS}

Bacterial strains and cultivation. Thiobacillus acidophilus ATCC $27897^{\mathrm{T}}$ ( $^{\mathrm{T}}=$ type strain) was studied. The following strains were used as the reference organisms: Acidiphilium angustum ATCC $35903^{\mathrm{T}}$, Acidiphilium cryptum ATCC $33463^{\mathrm{T}}$, Acidiphilium multivorum AIU301 ${ }^{\mathrm{T}}$, Acidiphilium rubrum ATCC $35905^{\mathrm{T}}$, Acidiphilium organovorum ATCC $43141^{\mathrm{T}}$ and Acidiphilium sp. strains St1-5 and St1-7. All strains with ATCC numbers were obtained from the
American Type Culture Collection (Rockville, MD, USA). A. multivorum AIU301 ${ }^{\mathrm{T}}$ was isolated from acidic mine drainage (Wakao et al., 1994). All other strains were isolated newly by us from acidic mine water. All test organisms were grown aerobically at $30^{\circ} \mathrm{C}$ in GYS medium, a chemically defined medium ( $\mathrm{pH} \mathrm{3.5)}$ which consisted of a mineral base RM2 (Hiraishi \& Kitamura, 1984), $15 \mathrm{mM}$ glucose as the sole carbon source and $0.03 \%(\mathrm{w} / \mathrm{v})$ yeast extract as the growth factor. T. acidophilus was also grown chemolithotrophically with elemental sulphur as the energy source as described by Harrison (1983). For chemical and genetic testing, cells were harvested by centrifugation from a culture at the late-exponential phase of growth, washed twice with sterile $50 \mathrm{mM}$ phosphate buffer $(\mathrm{pH} 6.8)$ and pelleted. The cell pellets were used immediately for analysis or stored at $-20^{\circ} \mathrm{C}$ until they were analysed.

Analysis of BChls. Lipophilic pigments were extracted from fresh wet cells with acetone-methanol $(7: 2, \mathrm{v} / \mathrm{v})$, evaporated in vacuum and analysed by reverse-phase HPLC with a Shimadzu Liquid Chromatograph LC-10A equipped with a Beckman Ultrasphere ODS column (4.6 i.d. $\times 250 \mathrm{~mm})$ in a column oven at $30^{\circ} \mathrm{C}$. Samples were eluted with methanol at a flow rate of $1 \mathrm{ml} \mathrm{min}^{-1}$ and monitored with a photodiode array detector, Shimadzu SPD-10A, in a wavelength range of $350-800 \mathrm{~nm}$. Post-run data analysis was performed with the Shimadzu CLASS-M10A program. For the identification and quantification of BChls, parameters for peak identification and calibration of detector response factors were set in the program on the basis of HPLC data on a known concentration of $A$. rubrum $\mathrm{Zn}-\mathrm{BChl} a$ which had been determined spectrophotometrically (Wakao et al., 1996). BChl $a$ and bacteriopheophytin (BPhe) purified from a purple phototrophic bacterium, Rhodobacter sphaeroides DSM $158^{\mathrm{T}}$, were also used as the standard pigments. Although zinc-chelated $\mathrm{BChl}$ should be called zinc-BPhe more precisely, we used herein the term $\mathrm{Zn}-\mathrm{BChl}$ for convenience.

Analysis of carotenoids. Pigments extracted as noted above were analysed by HPLC equipped with a $\mu$ Bondapak C18 column $(8 \mathrm{~mm}$ i.d. $\times 100 \mathrm{~mm})$ (Waters). Carotenoid components were eluted with methanol at flow rate of $2 \mathrm{ml} \mathrm{min}^{-1}$ and detected with a MCPD-3600 photodiode array detector (Otsuka Electronics) in a wavelength range of $250-600 \mathrm{~nm}$ (Takaichi \& Shimada, 1992). For spectrophotometric measurement of carotenoids, the following extinction coefficients in methanol were used: $150 \mathrm{mM}^{-1} \mathrm{~cm}^{-1}$ at 492 and $480 \mathrm{~nm}$ for spirilloxanthin and rhodovibrin, respectively. Major carotenoids were also purified by column chromatography on silica gel 60 (Merck). Molecular masses were determined by field-desorption mass spectrometry with a double-focusing gas chromatograph-mass spectrometer equipped with a field desorption apparatus (Hitachi) (Takaichi, 1993). Spirilloxanthin purified from a purple phototrophic bacterium, Rhodospirillum rubrum ATCC $11170^{\mathrm{T}}$, was used as the standard.

DNA-DNA hybridization. Genomic DNA was extracted and purified by the method of Marmur (1961). DNA-DNA pairing studies were performed by the quantitative dot-blot hybridization method with biotin labelling and colorimetric detection as reported previously (Hiraishi et al., 1991).

Analysis of 16S rDNA. 16S rRNA gene fragments that corresponded to positions 8 to 1510 of Escherichia coli $16 \mathrm{~S}$ rRNA (Brosius et al., 1978) were amplified directly from the cell lysate by PCR with Taq DNA polymerase (Takara 
Shuzo) and a pair set of eubacterial universal primers $27 \mathrm{f}$ and 1492r (Lane, 1991). PCR products were treated with a chloroform/isoamyl alcohol mixture and purified by the PEG precipitation method (Kusukawa et al., 1991; Hiraishi et al., 1995). 16S rDNA was sequenced with a SequiTherm Long-Read Cycle sequencing kit (Epicentre Technologies) with fluorescent primers and analysed with a Pharmacia ALF DNA sequencer as described previously (Hiraishi et al., 1994). RFLP analysis of $16 \mathrm{~S}$ rDNA was performed as previously reported (Hiraishi et al., 1995).

Analysis of puf genes. PCR amplification of puf genes was performed as described previously (Nagashima et al., 1997a, 1997b). A $2 \cdot 1 \mathrm{~kb}$ fragment that corresponded to a continuous nucleotide stretch between $p u f B$ and $p u f M$ was amplified with a pair set of primers, B140F (5'-TGGCASTGGCGYCCGTG( $\left.i-3^{\prime}\right)$ and MR (5'-CCATSGTCCAGCGCCAGA$\left.3^{\prime}\right)$. PCR experiments were also performed with other two pair sets of primers, B140f vs L810R (5'-TTGAGCCACCAGCTCACACA-3') and L810F (5'-TGGTGGAGCYGGTGGCTCAA-3') vs MR, resulting in generation of a $1.2 \mathrm{~kb}$ fragment between pufB and pufL and of a $0.9 \mathrm{~kb}$ fragment between pufL and pufM. PCR products were treated with chloroform/isoamyl alcohol, purified by agarose gel electrophoresis and glass binding with a Takara EasyTrap version 2 kit and sequenced directly by fluorescent cycle sequencing with primers previously described (Nagashima et al., 1997b). The two fragments of $1 \cdot 2$ and $0.9 \mathrm{~kb}$ were also subcloned by the TA cloning method (Marchuk et al., 1991) with a pT7Blue T-Vector kit (Novagen). Transformation of E. coli JM 109 was carried out according to a standard manual of molecular cloning (Sambrook et al., 1989). Plasmid DNA was isolated and purified by using a Pharmacia FlexiPrep kit according to the manufacturer's instructions. The subcloned DNA sequences were determined by cycle sequencing with $\mathrm{pUC} / \mathrm{M} 13$ and $\mathrm{T} 7$ promoter universal primers. All reactions were analysed with a Pharmacia ALF DNA sequencer and a Perkin-Elmer ABI 373A DNA sequencer.

Phylogenetic analysis. Sequence data were compiled with the GENETYX-MAC program package (Software Development). Multiple alignment of sequence was performed with the CLUSTAL w program (Thompson et al., 1991). Evolutionary distances were calculated by using Kimura's two-parameter model (Kimura, 1980). Phylogenetic trees were reconstructed by the neighbour-joining method (Saitou \& Nei, 1987), and the topology of trees was evaluated by bootstrapping with 1000 resamplings (Felsenstein, 1985). Alignment positions with gaps and unidentified bases were excluded from the calculations.

\section{RESULTS}

\section{S rDNA sequence comparisons}

The phylogenetic relationships between $T$. acidophilus and Acidiphilium species were re-examined based on $16 \mathrm{~S}$ rDNA sequences. Although the sequence data on T. acidophilus was already available from the DDBJ, EMBL and GenBank databases before this study, there were large numbers of undetermined positions. To ascertain the exact phylogenetic position of $T$. acidophilus, therefore, we determined nearly complete sequences of the 16S rDNA of $T$. acidophilus and related acidophilic organisms. Binary sequence com- parisons indicated that the $16 \mathrm{~S}$ rDNA of T. acidophilus was most closely related to the 16S rDNAs of $A$. angustum and A. rubrum at a similarity level of $98.3 \%$ (corrected distance $=0.0168$ ). A neighbour-joining phylogenetic tree was constructed on the basis of the distance matrix data on the test strains and several reference bacteria (Fig. 1). The tree showed that $T$. acidophilus fell into a cluster of the genus Acidiphilium with $A$. angustum and $A$. rubrum as its closest relatives. The monophyly of the cluster of the genus Acidiphilium and of the subcluster of $T$. acidophilus with $A$. angustum and the related strains as the sister group was supported by nearly $100 \%$ levels of bootstrap confidence. The results of our phylogenetic studies supported the previous results on the phylogeny of Acidiphilium species and related acidophiles (Lane et al., 1985, 1992; Sievers et al., 1994; Kishimoto et al., 1995b).

\section{Genomic DNA relatedness}

Interrelationships between $T$. acidophilus and Acidiphilium species were also studied by genomic DNA-DNA hybridization assays (Table 1). The DNA of $T$. acidophilus had $18-24 \%$ binding levels to those of A. angustum and A. rubrum and 9-11\% to those of other Acidiphilium strains tested. The low but significant levels of DNA-DNA relatedness between T. acidophilus and A. angustum or A. rubrum were in accordance with the results of the $16 \mathrm{~S}$ rDNA-based phylogenetic analysis. A high level of similarity between $A$. angustum and $A$. rubrum in the $16 \mathrm{~S}$ rDNA structure and genomic DNA relatedness, as reported here and elsewhere (Wakao et al., 1994; Kishimoto et al., 1995b), suggest synonymy of the two species names. In this study, 'Thiobacillus organoparus' (Markosyan, 1973), an acidophilic facultative chemolithotroph similar to T. acidophilus, was not used, since the former species is probably a synonym of the latter in view of the high level of DNA-DNA homology between the two (Katayama-Fujimura et al., 1983). The results of DNA-DNA hybridization assays indicate that $T$. acidophilus is phylogenetically related to, but distinct from, the previously known species of the genus Acidiphilium.

\section{Photosynthetic pigments}

Comparative HPLC assays of the lipid extracts of $T$. acidophilus and $A$. rubrum demonstrated that the former organism produced much smaller but appreciable amounts of photopigments than the latter (Fig. 2). By comparing HPLC elution times and absorption spectrum patterns (not shown) of the separated components, the main pigment of $T$. acidophilus was identified as $\mathrm{Zn}-\mathrm{BChl} a$. In all other test strains of Acidiphilium, $\mathrm{Zn}-\mathrm{BChl} a$ as well as $\mathrm{Mg}-\mathrm{BChl} a$ and BPhe were detected by HPLC. The contents of these photopigments varied significantly among the strains tested, whereas $\mathrm{Zn}-\mathrm{BChl} a$ always predominated in all 
A. Hiraishi and others

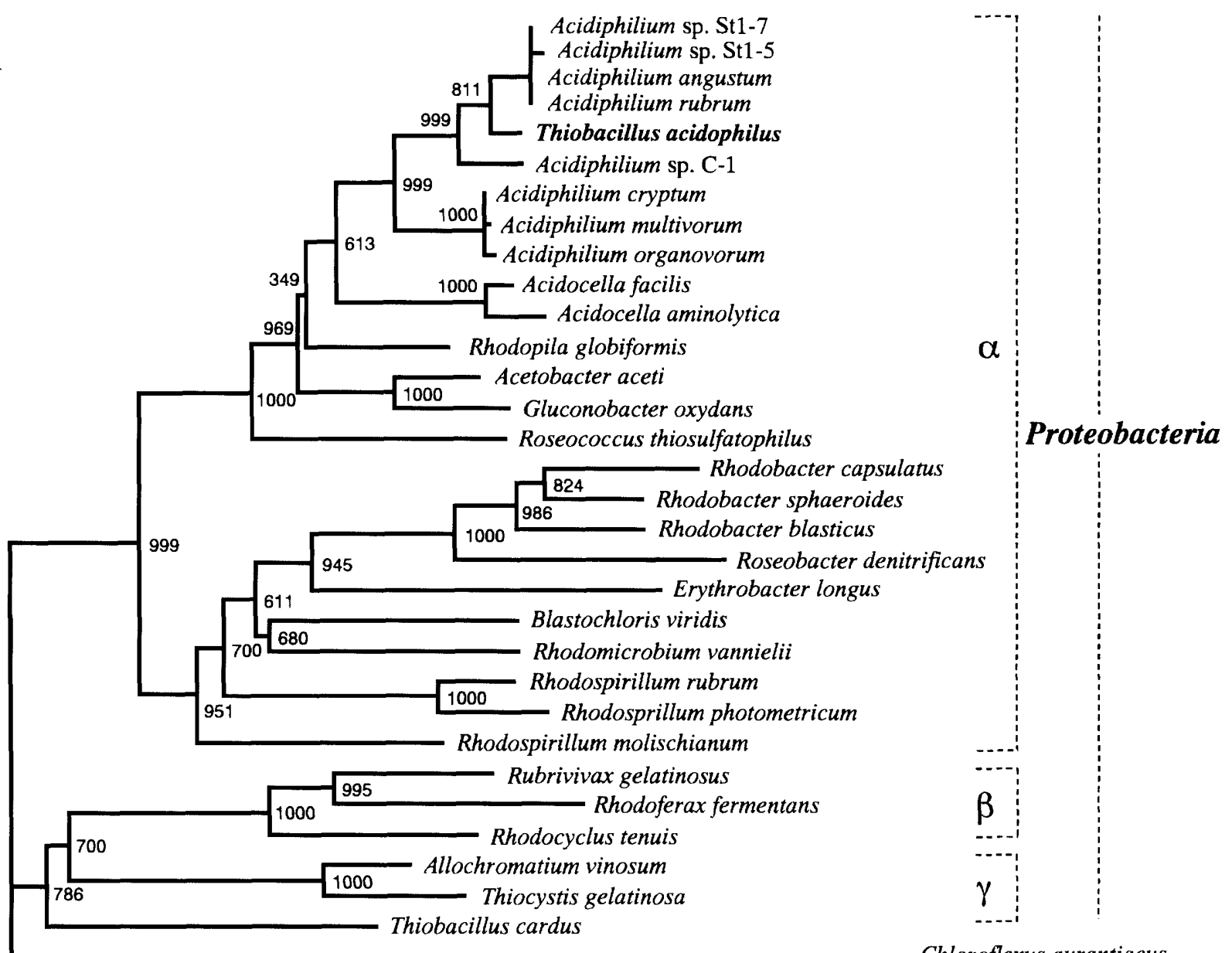

0.1

Fig. 1. Distance matrix tree showing phylogenetic affiliations of Thiobacillus acidophilus and other species of Proteobacteria based on 16S rDNA sequences. Chloroflexus aurantiacus was used as a member of outgroups to root the tree. Bootstrap values obtained with 1000 bootstrap resamplings are given at branching points of interest. Bar, 10 nucleotide substitutions per 100 nucleotides. The organisms and their sequences used in the analysis are as follows: Acetobacter aceti, D30768; Acidiphilium angustum, D30772; Acidiphilium cryptum, D30773; Acidiphilium multivorum, AB006712; Acidiphilium organovorum, D30775; Acidiphilium rubrum, D30776; Acidiphilium sp. C-1, D30769; Acidiphilium sp. St1-5, D86508; Acidiphilium sp. St1-7, D86509; Acidocella aminolytica, D30771; Acidocella facilis, D30774; Blastochloris viridis (formerly Rhodopseudomonas viridis), D25314; Chloroflexus aurantiacus, D32255; Allochromatium vinosum (formerly Chromatium vinosum), M26629; Erythrobacter longus, M59062; Gluconobacter oxydans, X73820; Rhodobacter blasticus, D16429; Rhodobacter capsulatus, D16428; Rhodobacter sphaeroides, D16425; Rhodocyclus tenuis, D16208; Rhodoferax fermentans, D16211; Rhodomicrobium vannielii, M34127; Rhodopila globiformis, D86513; Rhodospirillum molischianum, M59067; Rhodospirillum photometricum, D30777; Rhodospirillum rubrum, D30778; Roseobacter denitrificans, M59063; Roseococcus thiosulfatophilus, X72908; Rubrivivax gelatinosus, D16213; Thiobacillus acidophilus, D86511; Thiobacillus caldus, X29975; Thiocystis gelatinosa, D50655.

test organisms (Table 2). The molar ratio of $\mathrm{Zn}-\mathrm{BChl}$ $a: \mathrm{Mg}-\mathrm{BChl} a: \mathrm{BPhe}$ in the test organisms was relatively constant; for example, the mean ratio of the pigments with a molar basis of BPhe was $13: 2: 1$ in the high $\mathrm{Zn}-\mathrm{BChl}$ producers $A$. angustum and $A$. rubrum. In the strains showing low contents of the pigments (i.e. A. cryptum, A. multivorum and A. organovorum), the relative contents of $\mathrm{Mg}-\mathrm{BChl} a$ was lowered, and those of BPhe were increased compared to the high $\mathrm{Zn}$ BChl producers. These may be due to pheophytinization of a small amount of the $\mathrm{Mg}-\mathrm{BChl} a$ during the extraction of pigments or HPLC analysis. Possibly for this reason, $\mathrm{Mg}-\mathrm{BChl}$ a was hardly detected in T. acidophilus.

HPLC experiments also revealed that $T$. acidophilus and all Acidiphilium species contained spirilloxanthin as the sole or predominant carotenoid component (Fig. 2 and Table 2). The major carotenoid component purified from these bacteria had absorption maxima at $317,384,464,491$ and $524 \mathrm{~nm}$ in methanol. This component showed an HPLC retention time corre- 
Table 1. Genomic DNA relatedness between Thiobacilus acidophilus and members of the genus Acidiphilium

\begin{tabular}{|c|c|c|c|}
\hline \multirow[t]{2}{*}{ Strain } & \multirow{2}{*}{$\begin{array}{c}\text { DNA G }+C \\
\text { content } \\
(\mathrm{mol} \%)\end{array}$} & \multicolumn{2}{|c|}{$\begin{array}{l}\text { Hybridization (\%) with } \\
\text { labelled DNA from: }\end{array}$} \\
\hline & & ATCC $27897^{\mathrm{T}}$ & ATCC $35905^{T}$ \\
\hline Thiobacillus acidophilus ATCC $27897^{T}$ & $63 \cdot 5 *$ & 100 & 24 \\
\hline Acidiphilium angustum ATCC $35903^{\mathrm{T}}$ & $63 \cdot 4 \dagger$ & 18 & 98 \\
\hline Acidiphilium cryptum ATCC $33463^{\mathrm{T}}$ & $67 \cdot 3 \dagger$ & 8 & 11 \\
\hline Acidiphilium multivorum AIU301 ${ }^{\mathrm{T}}$ & $67 \cdot 6 \dagger$ & 10 & 10 \\
\hline Acidiphilium organovorum ATCC $43141^{T}$ & $67 \cdot 4 \dagger$ & 10 & 9 \\
\hline Acidiphilium rubrum ATCC $35905^{\mathrm{T}}$ & $63 \cdot 2 \dagger$ & 22 & 100 \\
\hline
\end{tabular}

* Cited from Katayama-Fujimura et al. (1983).

$\dagger$ Cited from Wakao et al. (1994).

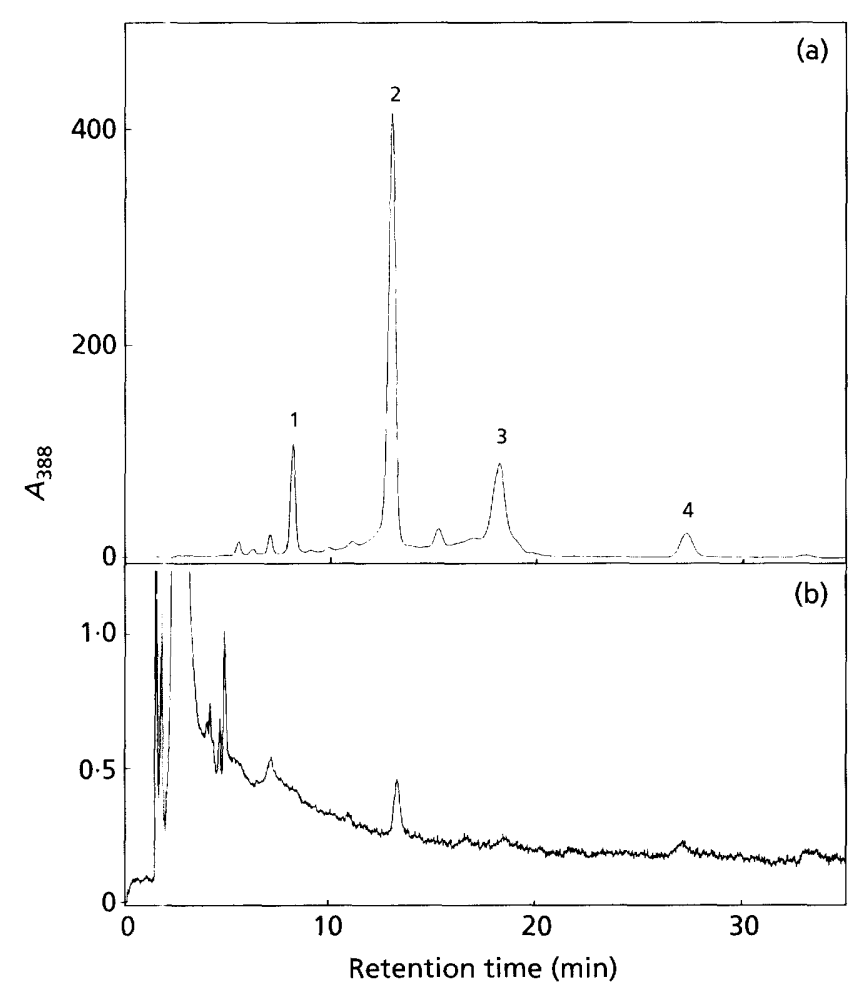

Fig. 2. HPLC analysis of the pigment extract of Thiobacillus acidophilus (b) compared with the extract of Acidiphilium rubrum (a). Peaks: 1, Mg-BChl a; 2, Zn-BChl a; 3, spirilloxanthin; 4, BPhe.

sponding to that of the authentic spirilloxanthin from the purple phototrophic bacterium Rhodospirillum rubrum. Mass spectroscopy showed that the carotenoid component from A. rubrum, the highest pigment producer, had a molecular mass of 596, thereby confirming it to be spirilloxanthin. A. cryptum and $A$. organovorum also produced a minor carotenoid component, which was identified as rhodovibrin on the basis of its HPLC retention time and absorption maxima at 465,489 and $521 \mathrm{~nm}$. This component is known to be an intermediate in spirilloxanthin biosynthesis in the purple bacteria.

While the liquid culture of $T$. acidophilus looked colourless, the massive cell pellet harvested by centrifugation was pale brown, probably due to the production of the photopigments. Direct spectrophotometric measurement of the acetone/methanol extract $(3 \mathrm{ml})$ from the cell pellet (wet wt $1 \mathrm{~g}$ ) detected only a weak peak with an absorption maximum at $763 \mathrm{~nm}$, which is characteristic of $\mathrm{Zn}-\mathrm{BChl} a$ (Wakao et al., 1996).

\section{Structure of puf genes}

In the purple bacteria, the genes encoding the photosynthetic reaction centre proteins and the core light-harvesting complex form an operon called $p u f$. This gene construction has been shown to be wellconserved not only among the species of the anaerobic photosynthetic bacteria but also in Acidiphilium species (Nagashima et al., 1997a, b). Using the PCR technique, DNA fragments between $p u f B$ and $p u f M$ that covered a continuous $2.1 \mathrm{~kb}$ stretch of the puf genes were successfully amplified from $T$. acidophilus cells and sequenced.

The primary sequence of the puf genes of $T$. acidophilus contained three ORFs corresponding to pufA, pufL and pufM (data not shown). The levels of amino acid sequence similarity between $T$. acidophilus and Acidiphilium species were $88-93 \%$ in the $\mathrm{L}$ and $\mathrm{M}$ subunits, whereas much lower levels of similarity were found between T. acidophilus and other photosynthetic bacteria (Fig. 3). It has been shown that the $\mathrm{L}$ and $\mathrm{M}$ subunits of Acidiphilium species have one characteristic replacement of an amino acid in the region around the special pair when the three-dimensional structures of the reaction centres of Blastochloris viridis (formerly Rhodopseudomonas viridis) (Deisenhofer et al., 1995) and Rhodobacter sphaeroides (Allen et al., 1987) are 
A. Hiraishi and others

Table 2. Bacteriochlorophyll and carotenoid contents of Thiobacillus acidophilus and Acidiphilium species

Rhod, Rhodovibrin; Spir, spirilloxanthin.

\begin{tabular}{|c|c|c|c|c|c|}
\hline \multirow[t]{2}{*}{ Test organism } & \multicolumn{5}{|c|}{ Pigment content (nmol $g^{-1}$ dry wt) } \\
\hline & Zn-BChl $a$ & $\operatorname{Mg-BChl~} a$ & BPhe & Spir & Rhod \\
\hline Thiobacillus acidophilus ATCC $27897^{\mathrm{T}}$ & $2 \cdot 3$ & 0 & $0 \cdot 8$ & $3 \cdot 3$ & 0 \\
\hline Acidiphilium angustum ATCC $35903^{\mathrm{T}}$ & 180 & 26 & 14 & 115 & 0 \\
\hline Acidiphilium cryptum ATCC $33463^{\mathrm{T}}$ & 57 & $5 \cdot 1$ & $5 \cdot 1$ & 37 & $1 \cdot 5$ \\
\hline Acidiphilium multivorum AIU $301^{\mathrm{T}}$ & 67 & $8 \cdot 8$ & $5 \cdot 9$ & 54 & 0 \\
\hline Acidiphilium organovorum ATCC $43141^{\mathrm{T}}$ & $6 \cdot 7$ & $0 \cdot 4$ & $0 \cdot 9$ & $6 \cdot 0$ & $0 \cdot 4$ \\
\hline Acidiphilium rubrum ATCC $35905^{\mathrm{T}}$ & 810 & 120 & 61 & 510 & 0 \\
\hline Acidiphilium sp. St 1-5 & 170 & 25 & 13 & 100 & 0 \\
\hline Acidiphilium sp. St 1-7 & 130 & 20 & 11 & 82 & 0 \\
\hline
\end{tabular}

\begin{tabular}{|c|c|c|}
\hline & $\begin{array}{l}\text { Sequence } \\
\text { similarity (\%) }\end{array}$ & \\
\hline Zn-BChl producers & & $\$ 170$ \\
\hline Thiobacillus acidophilus & 100.0 & HLDWASNंTGYNY INFEYNंPMHMVAVT \\
\hline Acidiphilium angustum & 93.3 & HLDWVSNTGYNY INFEYNPMHMVAVT \\
\hline Acidiphilium rubrum & 93.3 & HLDWVSNTGYNY INFEYNPMHMVAVT \\
\hline Acidiphilium cryptum & 88.3 & HLDWVSNTGYAYLNFEYNPMHMVAVT \\
\hline Acidiphilium multivorum & 87.9 & HLDWVSNTGYAYLNFEYNPMHMVAVT \\
\hline Acidiphilium organovorum & 88.1 & HLDWVSNTGYAYLNFEYNPMHMVAVT \\
\hline \multicolumn{3}{|l|}{ BChl producers } \\
\hline Rhodopila globiformis & 70.6 & HLDWVSNTGYQYLHFHYNPAHMIAIS \\
\hline Rhodospirillum rubrum & 68.2 & HLDWVSNTGYQYANFHYNPAHMLGIT \\
\hline Rhodospirillum photometricum & 64.3 & HLDWVSNIGYQFLHFHYNPAHMIGIT \\
\hline Rhodospirillum molischianum & 68.3 & HLDWVSNVGYQFLHFHYNPAHMIAIS \\
\hline Rubrivivax gelatinosus & 72.3 & HLDWVSNVGYQYLHFHYNPAHMLAIT \\
\hline Rhodoferax fermentans & 70.9 & HLDWGSNVGYQYLHFHYNPAHMLAIS \\
\hline Rhodocyclus tenuis & 69.7 & HLDWVSNTGYQYLHFHYNPGHMLGIA \\
\hline Allochromatium vinosum & 68.7 & HLDWVSNVGYQFLNFHYNPAHMLAIT \\
\hline Thiocystis gelatinosa & 69.3 & HLDWVSNVGYQFLHFHYNPAHMLAIT \\
\hline Blastochloris viridis & 61.6 & HLDWVNNFGYQYLNWHYNPGHMSSVS \\
\hline Rhodomicrobium vannielii & 70.3 & HLDWVSNTGYQYLHFHYNPAHMLAIS \\
\hline Rhodobacter capsulatus & 61.6 & HLDWVSNTGYTYGNFHYNPFHMLGIS \\
\hline Rhodobacter sphaeroides & 63.6 & HLDWVSNTGYTYGNFHYNPAHMIAIS \\
\hline Rhodobacter blasticus & 61.8 & HLDWVSNTGYTYGNFHYNPAHMLGIS \\
\hline Roseobacter denitrificans & 65.5 & HLDWVSNVGYAYLHFHYNPAHMLAVT \\
\hline Erythrobacter longus & 62.1 & HLDWVSYTGYNYVNFHYNPVHMLAIT \\
\hline \multirow[t]{2}{*}{ Chloroflexus aurantiacus } & 45.7 & HLDWVSNFGYRYNNFFYNPFHAIGIT \\
\hline & & $\star \star \star \star * \quad \star \star \star \quad \quad * \star * *$ \\
\hline
\end{tabular}

Fig. 3. Amino acid sequence similarity in the $L$ and $M$ subunits of the photosynthetic reaction centre between Thiobacillus acidophilus and other photosynthetic bacteria and alignment of a part of the $L$ subunit amino acid residues around the special pair. Asterisks mark identical residues in all species compared. One characteristic replacement of amino acid specific to Acidiphilium is shown by an arrow.

taken into account for comparison (Nagashima et al., 1997b). This is at Glu L168, at which histidine occurs in the purple bacteria in general. The occurrence of glutamic acid at this position was also the case in $T$. acidophilus (Fig. 3).

A phylogenetic tree of the reaction centre proteins was constructed on the basis of the present data (Fig. 4). The topography of the tree was similar to that of $16 \mathrm{~S}$ rDNA sequence-based tree in the relationships be- tween $T$. acidophilus and Acidiphilium species and between the Acidiphilium cluster and the phototrophic bacteria of the $\alpha$-subclass of the Proteobacteria. The fact that the phototrophic bacteria of the $\beta$ - and $\gamma$ subclasses were positioned among members of the $\alpha$ subclass of the phototrophs has been explained by considering possible lateral gene transfer (Nagashima et al., 1997a).

\section{Analysis of lithotrophically growing cells}

Since all established species of the genus Acidiphilium and the related new genus Acidocella (Kishimoto et al., 1995b) have been reported to be unable to grow with reduced sulphur compounds as energy sources (Harrison, 1989), it seemed curious that the sulphuroxidizing bacterium $T$. acidophilus has close phylogenetic relationships to those acidophilic chemoorganotrophic bacteria. This situation led us to reexamine whether $T$. acidophilus truly can oxidize reduced sulphur compounds as energy sources for growth, and this gave positive results in agreement with the previous reports (Guay \& Silver, 1975; Harrison, 1983; Norris et al., 1986; Pronk et al., 1990; Meulenberg et al., 1992).

We compared the $16 \mathrm{~S}$ rDNA structure of the sulphurgrown cells with that of the heterotrophically grown cells of $T$. acidophilus by studying RFLP patterns with HaeIII, HhaI, MspI and RsaI. The resulting $16 \mathrm{~S}$ rDNA-RFLP patterns of the two cultures were identical and matched completely with the computerpredicted RFLP profiles (not shown). The DNA DNA binding level between chemo-organotrophically grown and chemolithotrophically grown cells of $T$. acidophilus was $100 \%$. PCR amplification of the puf gene from the sulphur-grown cells was also successful. These findings excluded the possibility that $T$. acidophilus is a mixed culture of a chemoorganotrophic species and a chemolithotrophic one. 

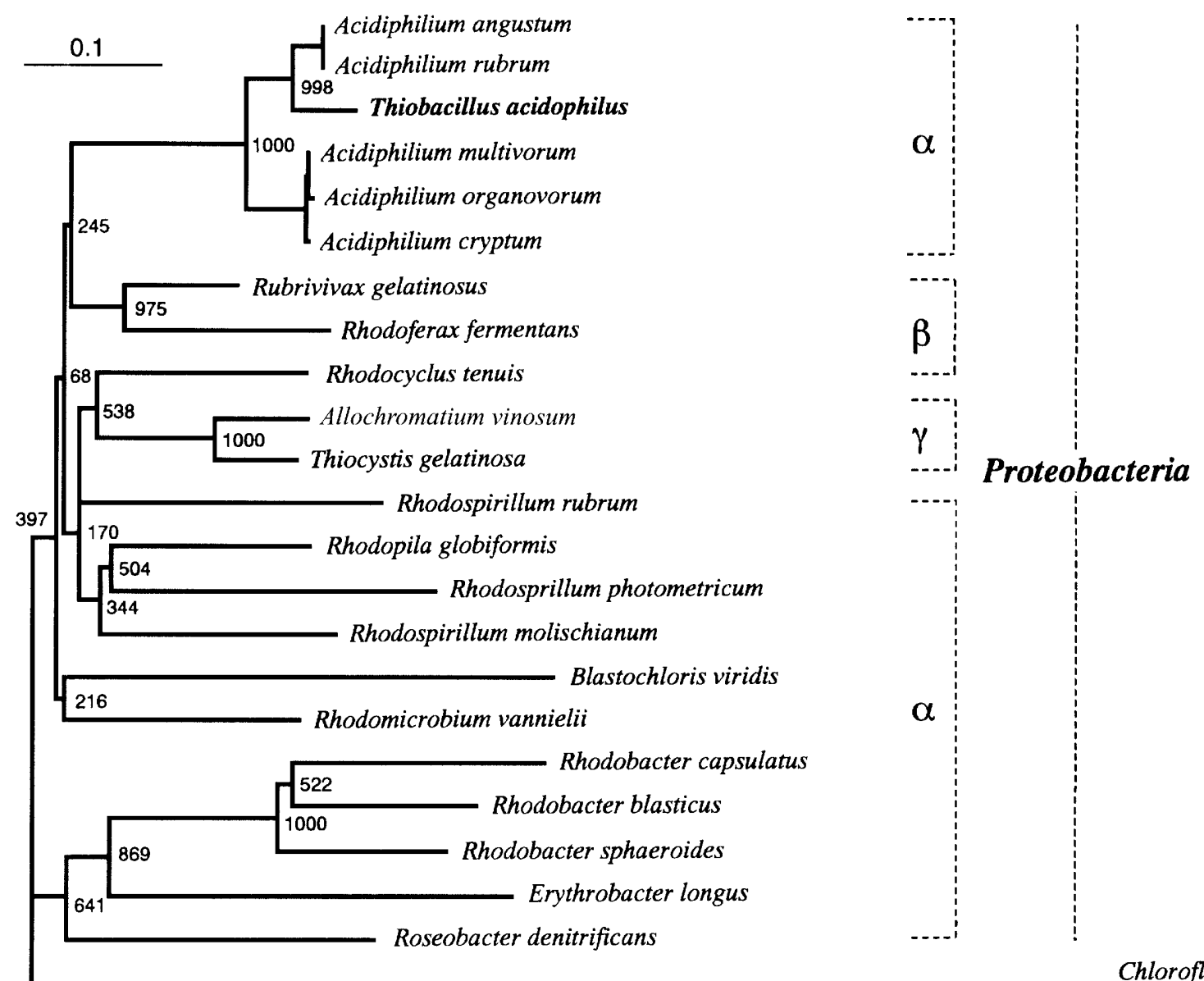

Chloroflexus aurantiacus

\begin{abstract}
Fig. 4. Distance matrix tree showing phylogenetic relationships between $T$. acidophilus and photosynthetic proteobacteria based on continuous amino acid sequences of the $L$ and $M$ subunit proteins of the puf gene. Chloroflexus aurantiacus was used as a member of outgroups to root the tree. Bootstrap values obtained with 1000 bootstrap resamplings are given at branching points of interest. Bar, 10\% amino acid substitutions. The organisms and their sequences used in the analysis are as follows: Acidiphilium angustum, AB005219; Acidiphilium cryptum, AB005220; Acidiphilium multivorum, AB005221; Acidiphilium organovorum, AB005222; Acidiphilium rubrum, AB005218; Blastochloris viridis (formerly Rhodopseudomonas viridis), X03915; Chloroflexus aurantiacus, X14979; Allochromatium vinosum (formerly Chromatium vinosum), D50647; Erythrobacter longus, D50648; Rhodobacter blasticus, D50649; Rhodobacter capsulatus, Z11165; Rhodobacter sphaeroides, X63404 and K00827; Rhodocyclus tenuis, D50651; Rhodoferax fermentans, D50650; Rhodomicrobium vannielii, D50652; Rhodopila globiformis, unpublished data (A. Hiraishi); Rhodospirillum molischianum, D50654; Rhodospirillum photometricum, D50681; Rhodospirillum rubrum, J03731; Roseobacter denitrificans; X57597; Rubrivivax gelatinosus, D16822; Thiobaciilus acidophilus, AB013379; Thiocystis gelatinosa, D50653.
\end{abstract}

\section{DISCUSSION}

As reported here, the molecular genetic analysis based on 16S rDNA sequence and DNA-DNA relatedness clearly demonstrates that $T$. acidophilus falls into a cluster of the genus Acidiphilium with $A$. angustum and A. rubrum as its nearest phylogenetic neighbours. These molecular data are in agreement with the previous findings as to the phylogeny of $T$. acidophilus, Acidiphilium species and related acidophiles (Lane et al., 1985, 1992; Sievers et al., 1994; Kishimoto et al., 1995b). Although T. acidophilus is most closely related to $A$. rubrum, it is clear that this bacterium represents a distinct species within the genus Acidiphilium, in view of the DNA-DNA hybridization data. These results unequivocally warrant reclassification of $T$. acidophilus as a new distinct species of this genus from a phylogenetic point of view.

The genus Acidiphilium was first proposed to accommodate strictly aerobic, chemo-organotrophic, acidophilic bacteria that grow under strongly acidic conditions ( $\mathrm{pH} \mathrm{2-6)}$ (Harrison, 1983). Later some members of this genus have been shown to produce BChls during aerobic growth (Wakao et al., 1993, 1994; Kishimoto et al., 1995a). This finding, together with 16S rDNA-based phylogenetic information, has led to the emendation of the genus Acidiphilium concurrently with the transfer of the non-pigmentproducing species to the new genus Acidocella 
A. Hiraishi and others

Table 3. Differential characteristics of Acidiphilium acidophilum comb. nov. and other Acidiphilium species

Symbols and abbreviations: + , positive; $(+)$, weakly positive; - , negative; $\mathrm{W}$, white; PB, pale brown to pink for old cultures. Information from Guay \& Silver (1975), Harrison (1983), Katayama-Fujimura et al. (1983), Lobus et al. (1986), Wakao et al. (1994) and this study.

\begin{tabular}{|c|c|c|c|c|c|}
\hline Character & A. acidophilum & $\begin{array}{c}\text { A. angustum/ } \\
\text { A. rubrum }\end{array}$ & A. cryptum & A. multivorum & A. organovorum \\
\hline Colour of colonies & W, PB & Pink to red & $\mathrm{W}, \mathrm{PB}$ & $\mathrm{W}, \mathrm{PB}$ & W, PB \\
\hline Growth factor required & - & + & + & + & + \\
\hline \multicolumn{6}{|l|}{ Chemolithotrophic growth with: } \\
\hline Sulphur & + & - & - & - & - \\
\hline Thiosulphate & + & - & - & - & - \\
\hline \multicolumn{6}{|l|}{ Carbon source utilization: } \\
\hline Fumarate & - & - & - & + & - \\
\hline Succinate & - & - & - & + & + \\
\hline Ethanol & + & - & - & + & - \\
\hline Methanol & $(+)$ & - & - & + & - \\
\hline Glutamate & + & - & + & + & + \\
\hline DNA G $+\mathrm{C}$ content $(\mathrm{mol} \%)$ & $62 \cdot 9-63 \cdot 5$ & $63 \cdot 2-63 \cdot 4$ & $67 \cdot 3-68 \cdot 3$ & $66 \cdot 2-68 \cdot 1$ & $67 \cdot 4$ \\
\hline
\end{tabular}

(Kishimoto et al., 1995b). Recently, the main component of photopigments in A. rubrum has been found to be $\mathrm{Zn}-\mathrm{BChl}$ a (Wakao et al., 1996). Moreover, molecular genetic analyses have shown that all previously known species of the genus Acidiphilium emend. contain puf genes encoding proteins of the photosynthetic reaction centre and the core lightharvesting complex (Nagashima et al., 1997b). Thus, Acidiphilium species are now recognized as aerobic photosynthetic bacteria that are unique in containing Zn-BChl $a$.

In this context, we examined the photosynthetic properties of T. acidophilus compared with those of all established species of the genus Acidiphilium. $T$. acidophilus as well as all Acidiphilium species produced detectable amounts of $\mathrm{Zn}-\mathrm{BChl} a$ and carotenoids as reported here. The structural genes encoding the photosynthetic reaction centre of $T$. acidophilus were also detected and found to be similar to those of Acidiphilium species in primary structures and amino acid replacement around the special pair in the $\mathrm{L}$ subunit. The phylogenetic tree deduced from amino acid sequences of the $\mathrm{L}$ and $\mathrm{M}$ subunits demonstrates close relationships of $T$. acidophilus to Acidiphilium species with $A$. angustum and $A$. rubrum as its closest relatives, being consistent with the topography of the tree based on 16S rDNA sequences noted above.

Thiobacillus acidophilus differs from all known Acidiphilium species in the chemolithotrophic metabolism with reduced sulphur compounds. Nevertheless, the ability of $T$. acidophilus to produce the photopigments with $\mathrm{Zn}-\mathrm{BChl} a$ as the major component demonstrates its phenotypic similarity to members of the genus Acidiphilium, and this provides a firm basis for the taxonomic reassignment of $T$. acidophilus in that genus. Concurrent phenotypic studies have also shown that $T$. acidophilus and Acidiphilium species share a number of common characteristics useful for the circumscription of the genus but are distinguishable from each other in some phenotypes as described below. Thus, based on the phylogenetic and phenotypic information described here, we propose transfer of T. acidophilus (Guay and Silver) Harrison 1983 to the genus Acidiphilium as Acidiphilium acidophilum comb. nov. Diagnostic characteristics of this organism and other Acidiphilium species are shown in Table 3.

Following this proposal, the situation may call for emendation of the genus Acidiphilium, because this genus has previously been defined to accommodate only 'non-sulphur' chemo-organotrophic acidophiles (Kishimoto et al., 1995b). However, it is our view, at this time, that all members of the genus Acidiphilium need re-examining more thoroughly in terms of sulphur metabolism. A previous study suggested that $A$. cryptum was unable to use sulphur as the energy source for growth but that it had the capacity for sulphur oxidation (Harrison, 1983). More effective data on sulphur metabolism should be helpful for the emendation of the genus Acidiphilium in the future.

\section{Description of Acidiphilium acidophilum [Thiobacillus acidophilus (Guay and Silver) Harrison 1983] comb. nov.}

Acidiphilium acidophilum (a.ci.do'phi.lum. L. adj. acidus sour; M.L. neut. n. acidum acid; Gr. adj. philus loving; M.L. adj. acidophilum acid-loving).

The description of this species is based on information from Guay \& Silver (1975), Harrison (1983), Katayama-Fujimura et al. (1982, 1983, 1984), Norris et al. (1986), Mason et al. (1987), Pronk et al. (1990) and this study. Cells are rod-shaped, $0.5-0.8 \mu \mathrm{m}$ wide 
by $1.0-1.5 \mu \mathrm{m}$ long, occurring singly, pairs and rarely chains. Non-spore-forming. Motile or non-motile. Gram-negative. Colonies on agar media are round, regular, convex, slightly translucent, and white to cream; cell pellets harvested by centrifugation shows pale brown. Strictly aerobic facultative chemolithotrophs and mixotrophs growing with elemental sulphur as an energy source and with oxygen as the terminal electron acceptor. Thiosulphate, trithionate and tetrathionate also serve as electron donor. Neither sulphite, sulphide nor ferrous iron serves as electron donor. Do not denitrify. Polyhedral inclusion bodies (carboxysomes) are present in elemental sulphurgrown cells. Optimal growth occurs at $25-30{ }^{\circ} \mathrm{C}$ (range, $10.35^{\circ} \mathrm{C}$ ) and at $\mathrm{pH} 3 \cdot 0-3.5$ (range, $\mathrm{pH} 1.5$ $6 \cdot 0)$. No growth factor is required. Usable carbon sources are: L-arabinose, D-xylose, D-ribose, D-glucose, D-galactose, D-fructose, sucrose, glycerol, Dmannitol, ethanol, gluconate, L-malate, citrate, Lglutamate, L-histidine, L-proline, DL-aspartate. Methanol and $n$-propanol support weak growth. Not utilized are: L-sorbose, L-rhamnose, D-mannose, Dmaltose, lactose, cellobiose, trehalose, D-melibiose, raffinose, n-butanol, cyclohexanol, ascorbic acid, formate, acetate, propionate, $n$-butyrate, lactate, pyruvate, succinate, fumarate, $\alpha$-ketoglutarate, glutarate, glyoxylate, oxalate, adipate, pimerate, benzoate, $p$-hydroxybenzoate, $p$-aminobenzoate, Lalanine, L-serine, L-leucine, L-isoleucine, L-phenylalanine, L-tryptophan, L-cysteine and tyrosine. Ammonium salts but not nitrate salts are utilized as nitrogen source. $\mathrm{Zn}-\mathrm{BChl} a$ (bacteriochlorophyll $a$ chelated with zinc as the central metal) occurs in a very small amount. Ubiquinone-10 is the major respiratory quinone. The $\mathrm{G}+\mathrm{C}$ content of genomic DNA is $62.9-63.5 \mathrm{~mol} \%$. Source: originally isolated from an iron-oxidizing culture of Thiobacillus ferrooxidans and found in strongly acidic environments including mine water. Type strain: ATCC $27807^{\mathrm{T}}\left(=\mathrm{DSM} 700^{\mathrm{T}}\right)$.

\section{ACKNOWLEDGEMENTS}

This work was supported in part by the Grant-in-Aid from the Ministry of Education, Science, Culture and Sports, Japan (no. (19309008).

\section{REFERENCES}

Allen, J. P., Feher, G., Yeates, T. O., Komiya, H. \& Rees, D. C. (1987). Structure of the reaction center from Rhodobacter sphaeroides R-26: the cofactors. Proc Natl Acad Sci USA 84, 5730-5734.

Brosius, J, Palmer, J. L., Kennedy, J. P. \& Noller, H. F. (1978). Complete nucleotide sequence of a $16 \mathrm{~S}$ ribosomal RNA gene from Escherichia coli. Proc Natl Acad Sci USA 75, 4801-4805.

Deisenhofer, J., Epp, O., Sinning, I. \& Michel, H. (1995). Crystallographic refinement at $2 \cdot 3 \AA$ resolution and refined model of the photosynthetic reaction centre from Rhodopseudomonas viridis. J Mol Biol 246, 429-457.

Felsenstein, J. (1985). Confidence limits on phylogenies: an approach using the bootstrap. Evolution 39, 783-791.

Guay, R. \& Silver, M. (1975). Thiobacillus acidophilus sp. nov.; isolation and some physiological characteristics. Can $J$ Microbiol 21, 281-288.

Harrison, A. P., Jr (1983). Genomic and physiological comparisons between heterotrophic thiobacilli and Acidiphilium cryptum, Thiobacillus versutus sp. nov., and Thiobacillus acidophilus nom. rev. Int $J$ Syst Bacteriol 33, 211-217.

Harrison, A. P., Jr (1984). The acidophilic thiobacilli and other acidophilic bacteria that share their habitat. Annu Rev Microbiol 38, 265-292.

Harrison, A. P., Jr (1989). Genus Acidiphilium Harrison 1981, $211^{\text {AL }}$. In Bergey's Manual of Systematic Bacteriology, vol. 3, pp. 1863-1868. Edited by J. T. Staley, M. P. Bryant, N. Pfennig \& J. G. Holt. Baltimore: Williams \& Wilkins.

Hiraishi, A. \& Kitamura, H. (1984). Distribution of phototrophic purple nonsulfur bacteria in activated sludge systems and other aquatic environments. Bull Jpn Soc Sci Fish 50, 1929-1937.

Hiraishi, A., Hoshino, Y. \& Satoh, T. (1991). Rhodoferax fermentans gen. nov., sp. nov., a phototrophic purple nonsulfur bacterium previously referred to as the "Rhodocyclus gelatinosus-like" group. Arch Microbiol 155, 330-336.

Hiraishi, A., Shin, Y. K., Ueda, Y. \& Sugiyama, J. (1994). Automated sequencing of PCR-amplified 16S rDNA on "Hydrolink" gels. J Microbiol Methods 19, 145-154.

Hiraishi, A., Kamagata, Y. \& Nakamura, K. (1995). Polymerase chain reaction amplification and restriction fragment length polymorphism analysis of 16S rRNA genes from methanogens. $J$ Ferment Bioeng 79, 523-529.

Katayama-Fujimura, Y., Tsuzaki, N. \& Kuraishi, H. (1982). Ubiquinone, fatty acid and DNA base composition determination as a guide to the taxonomy of the genus Thiobacillus. $J$ Gen Microbiol 128, 1599-1611.

Katayama-Fujimura, Y., Enokizono, Y., Kaneko, T. \& Kuraishi, H. (1983). Deoxyribonucleic acid homologies among species of the genus Thiobacillus. J Gen Appl Microbiol 29, 287-295.

Katayama-Fujimura, Y., Kawashima, I., Tsuzaki, N. \& Kuraishi, H. (1984). Polyhedral inclusion bodies (carboxysomes) in Thiobacillus species with reference to the taxonomy of the genus Thiobacillus. J Gen Appl Microbiol 30, 21 1-222.

Kelly, D. P. \& Harrison, A. P., Jr (1989). Genus Thiobacillus Beijerinck 1904, 597 ${ }^{\mathrm{AL}}$. In Bergey's Manual of Systematic Bacteriology, vol. 3, pp. 1842-1858. Edited by J. T. Staley, M. P. Bryant, N. Pfennig \& J. G. Holt. Baltimore: Williams \& Wilkins.

Kimura, M. (1980). A simple method for estimating evolutionary rates of base substitution through comparative studies of nucleotide sequences. J Mol Evol 16, 111-120.

Kishimoto, N., Fukaya, F., Inagaki, K., Sugio, T., Tanaka, H. \& Tano, T. (1995a). Distribution of bacteriochlorophyll $a$ among aerobic and acidophilic bacteria and light-enhanced $\mathrm{CO}_{2}-$ incorporation in Acidiphilium rubrum. FEMS Microbiol Ecol 16, 291-296.

Kishimoto, N., Kosako, Y., Wakao, N., Tano, T. \& Hiraishi, A. (1995b). Transfer of Acidiphilium facilis and Acidiphilium aminolytica to the genus Acidocella gen. nov., and emendation of the genus Acidiphilium. Syst Appl Microbiol 18, 85-91.

Kusukawa, N., Uemori, T., Asada, K. \& Kato, I. (1990). Rapid and reliable protocol for direct sequencing of material amplified by the polymerase chain reaction. BioTechniques 9, 66-72.

Lane, D. J. (1991). 16S/23S rRNA sequencing. In Nucleic Acid Techniques in Bacterial Systematics, pp. 115-175. Edited by E. Stackebrandt \& M. Goodfellow. Chichester: Wiley.

Lane, D. J., Harrison, A. P., Jr, Stahl, D., Pace, B., Giovannoni, 
S. J., Olsen, G. J. \& Pace, N. R. (1992). Evolutionary relationships among sulfur- and iron-oxidizing eubacteria. $J$ Bacteriol 174, $269-278$

Lane, D. J., Stahl, D. A., Olsen, G. J., Heller, D. J. \& Pace, N. R. (1985). Phylogenetic analysis of the genera Thiobacillus and Thiomicrospira by 5S rRNA sequences. J Bacteriol 163, 75-81.

Lobos, J. H., Chisolm, T. E., Bopp, L. H. \& Holms, D. S. (1986). Acidiphilium organovorum sp. nov., an acidophilic heterotroph isolated from a Thiobacillus ferrooxidans culture. Int J Syst Bacteriol 36, 139-144.

Marchuk, D., Drumm, M., Saulino, A. \& Collins, F. S. (1991). Construction of T-vectors, a rapid and general system for direct cloning of unmodified PCR products. Nucleic Acids Res 19, 1154.

Markosyan, G. E. (1973). A new mixotrophic sulfur bacterium developing in acid media, Thiobacillus organoparus $\mathrm{sp}$. n. Dokl Akad Nauk SSSR 211, 1205-1208 (in Russian).

Marmur, J. (1961). A procedure for the isolation of deoxyribonucleic acid from micro-organisms. $J$ Mol Biol 3, 208-218.

Mason, J., Kelly, D. P. \& Wood, A. P. (1987). Chemolithotrophic and autotrophic growth of Thermothrix thiopara and some thiobacilli on thiosulphate and polythionates, and a reassessment of the growth yields of Thx. thiopara in chemostat culture. J Gen Microbiol 133, 1249-1256.

Meulenberg, R., Pronk, J. T., Hazeu, W., Bos, P. \& Kuenen, J. G. (1992). Oxidation of reduced sulfur compounds by intact cells of Thiobacillus acidophilus. J Bacteriol 150, 582-591.

Nagashima, K. V. P., Hiraishi, A., Shimada, K. \& Matsuura, K. (1997a). Horizontal transfer of genes coding for the photosynthetic reaction centers of purple bacteria. J Mol Evol 45, 131-136.

Nagashima, K. V. P., Matsuura, K., Wakao, N., Hiraishi, A. \& Shimada, K. (1997b). Nucleotide sequences of genes coding for photosynthetic reaction centers and light-harvesting proteins of Acidiphilium rubrum and related aerobic acidophilic bacteria. Plant Cell Physiol 38, 1249-1258.

Norris, P. R., Marsh, R. M. \& Lindstrom, E. B. (1986). Growth of mesophilic and thermophilic acidophilic bacteria on sulfur and tetrathionate. Biotechnol Appl Biochem 8, 318-329.

Pronk, J. T., Meulenberg, R., Hazeu, W., Bos, P. \& Kuenen, J. G. (1990). Oxidation of reduced inorganic sulfur compounds by acidophilic thiobacilli. FEMS Microbiol Rev 75, 293-306.
Saitou, N. \& Nei, M. (1987). The neighbor-joining method: a new method for reconstructing phylogenetic trees. Mol Biol Evol 4, 406-425.

Sambrook, J., Fritsch, E. F. \& Maniatis, T. (1989). Molecular Cloning : a Laboratory Manual, 2nd edn. Cold Spring Harbor, NY: Cold Spring Harbor Laboratory.

Shimada, K. (1995). Aerobic anoxygenic phototrophs. In Anoxygenic Photosynthetic Bacteria, pp. 105-122. Edited by R. E. Blankenship, M. T. Madigan \& C. E. Bauer. Dordrecht: Kluwer.

Sievers, M., Ludwig, W. \& Teuber, M. (1994). Phylogenetic positioning of Acetobacter, Gluconobacter, Rhodopila, and Acidiphilium species as a branch of acidophilic bacteria in the $\alpha$ subclass of Proteobacteria based on 16S ribosomal DNA sequences. Syst Appl Microbiol 17, 189-196.

Skerman, V. B. D., McGowan, V. \& Sneath, P. H. A. (1980). Approved lists of bacterial names. Int $J$ Syst Bacteriol 30 , 225-420.

Takaichi, S. (1993). Usefulness of field desorption mass spectrometry in determining molecular masses of carotenoids, natural carotenoid derivatives and their chemical derivatives. Org Mass Spectrom 28, 785-788.

Takaichi, S. \& Shimada, K. (1992). Characterization of carotenoids in photosynthetic bacteria. Methods Enzymol 213, 374-385.

Thompson, J. D., Higgins, D. G. \& Gibson, T. J. (1991). CLUSTAL $\mathrm{W}$ : improving the sensitivity of progressive multiple sequence alignment through sequence weighting, position-specific gap penalties and weight matrix choice. Nucleic Acids Res 22, 4673-4680.

Wakao, N., Shiba, T., Hiraishi, A., Ito, M. \& Sakurai, Y. (1993). Distribution of bacteriochlorophyll $a$ in species of the genus Acidiphilium. Curr Microbiol 27, 277-279.

Wakao, N., Nagasawa, N., Matsuura, T., Matsukura, H., Matsumoto, T., Hiraishi, A., Sakurai, Y. \& Shiota, H. (1994). Acidiphilium multivorum sp. nov., an acidophilic chemoorganotrophic bacterium from pyritic acid mine drainage. $J$ Gen Appl Microbiol 40, 143-159.

Wakao, N., Yokoi, N., Isoyama, N. \& 8 other authors (1996). Discovery of natural photosynthesis using zinc-containing bacteriochlorophyll in an aerobic bacterium Acidiphilium rubrum. Plant Cell Physiol 37, 889-893. 